\title{
Childhood Geography: a study about Children's Satisfaction with Housing in Buenos Aires Province, Argentina
}

\author{
Graciela Tonon $^{1}$ (D) $\cdot$ Claudia Mikkelsen ${ }^{2}$
}

Accepted: 30 November 2021 /Published online: 9 January 2022

(c) The Author(s), under exclusive licence to Springer Nature B.V. 2021

\begin{abstract}
This article presents the study of the characteristics and infrastructure of houses inhabited by children and their satisfaction with them. It embraces a sample of 580 12-year-olds children, living in the district of General Pueyrredón (PGP), an area located in the Southeast of the Province of Buenos Aires, Argentina. This survey was carried out in the framework of the research project acknowledged by the LOMASCyT Program of the National University of Lomas de Zamora, Argentina and developed by the UNICOM-Institute of Social Studies, of the School of Social Sciences. Specifically the core of this research considered the study and analysis of the following variables of children's lives, namely: the number of rooms in their houses, the number of bathrooms in their houses, the accessibility to own or shared room and own or shared bed for sleeping, having a space of their own to study, having water service, light and sewers in their houses, and the level of satisfaction with the house they inhabit.
\end{abstract}

Keywords Childhood $\cdot$ Housing $\cdot$ Infrastructure $\cdot$ Level of satisfaction

\section{Introduction}

In the field of Childhood Geography, it is possible to point out that the issues addressed turn around three large units; the geography of everyday life; the physical and material characteristics of places, and the function of the body as the first tool of space exploration (Malatesta \& Granados Sanchez, 2017). Within this framework, and in circumstances of confinement such as those that humanity currently goes through related with COVID-19 Pandemic, it is essential to consider housing as a

Graciela Tonon

gtonon1@palermo.edu

1 UNICOM, Institute of Social Studies of the School of Social Sciences, Universidad Nacional de Lomas de Zamora, Lomas de Zamora, Argentina

2 INHUS-CONICET-GESPyT-F.HUM-UNMdP, Mar del Plata and CIG-UNCPBA, Tandil, Argentina 
second territory, a shelter, a space of support, and also where difficulties, abuses and the first difficulties in childhood are made invisible.

The aim of this article describes the study of the characteristics and infrastructure of children's houses and their satisfaction with them. At the methodological level, we worked with a non-probabilistic, intentional sample of 580 12-year-oldschildren living in the district of General Pueyrredón (PGP), an area located in the Southeast of the Province of Buenos Aires, Argentina.

The survey was carried out in the framework of the research project acknowledged by the LOMASCyT Program of the National University of Lomas de Zamora, Argentina and developed by the UNICOM- Institute of Social Studies of the Faculty of School of Social Sciences. Specifically, the core of the research considered the description and analysis of the following variables of children's lives, namely: having water service, light and sewers in their houses, the number of rooms in their houses, the number of bathrooms in their houses, the accessibility to own or shared room and own or shared bed for sleeping, having their own space to study in their houses and the level of satisfaction with the house they inhabit.

\section{Children's Satisfaction with Housing}

Although the field of child well-being has been 50 years in the making (Ben-Arieh, 2010), the field of Childhood Geography in relation with children's satisfaction with the places where they live did not have the same level of development. Working on children's lives would contribute to recognize, identify and understand the territorial gaps and inequalities that boys and girls meet as protagonists, focusing on the identification of situations of spatial injustice of these groups (Tonon \& Mikkelsen, 2021).

The concept of satisfaction refers to a judgmental process in which individual asses the quality on the basis of their own unique set of criteria (Shin \& Johnson, 1978 quoted by Pavot \& Diener, 1993, p. 164). In this sense, analyzing children's satisfaction with their housing allows us to capture children's desires, aspirations and conflicts with the spaces where they live. As Clair (2018) pointed out, studies on the influence of housing on children have been limited and have been related more to the concerns of adults.

Since children live in places that are specific geographical cuts, it is necessary to understand their satisfaction with the houses they live in. In this sense, the concept of territory becomes relevant, as a social and historical construction visible in the materialization of human activities, as an appropriate space for a certain social relationship which shapes it and maintains it initiated from a form of power. Considering the territory as a social product implies recognizing in it diverse, supportive and at the same time conflicting social representations.

Lopes de Souza (1995) points out that the territory is fundamentally a space defined and delimited by and from power relations. The main issue here is not, certainly, to show what are the geo-ecological characteristics and natural resources of a certain area, what is produced or who produces in a given space, but which are the affective and identity links between a social group and its space (López de Souza, 1995). 
In this sense, the territory should be treated as a fundamental factor in the study and understanding of children's well-being, as well as the families of which they are members, taking care of it in a multi-scale approach in the locality, the neighborhood and/or housing.

Housing takes a central role in people's lives as it enables the satisfaction of the basic needs of families and society as a whole, as well as being the material center where the first skills for the social and cultural development of children are set up and learned. For example, the role of education is guaranteed and enhanced, since in the family-school link housing has a role of shelter and the possibility of returning home and developing there the activities assigned by teachers. Likewise it will be in the house where children carry out playful and/or sporting activities. It is in housing that children must receive the care of responsible adults, which care affects their physical and emotional health that results in critical long-term affective, warming and restraint benefits (Caramelo, 2018).

The importance of housing in children lives has been considered in reports from the UNICEF, the UN and the OCDE. Different authors studied the relation between housing and well-being, Evans, Saltzman and Cooperman (2001), Harkness and Newman (2005), Bradshaw and Richardson (2009), Coley, Leventhal, Lynch and Kull (2013), Rees and Bradshaw (2017).

In Latin America, the first studies on children' satisfaction with housing were developed in the twenty-first century. In the case of Argentina this topic has not been practically explored. In reference to the well-being of children in relation to their house, the neighborhood they live in and their satisfaction with them, we can mention the work of: Tonon and Mikkelsen (2019) who analyzed the concept of place through the eyes of children; Mikkelsen on the social space in which children live (2019); Tonon (2018) about the opinions, life experiences, and definitions of children in the province of Buenos Aires; Rees, Tonon, Mikkelsen and Rodriguez de la Vega (2017) about urban-rural variations in children's lives and subjective wellbeing, in which the authors measured the responses of children 8 and 10 years old with residence in the province of Buenos Aires, connecting two dimensions: housing/home and neighborhood, along with the gender variable; Tonon and Mikkelsen (2017) about the neighborhood as a social space from the eyes of children living in cities of the province of Buenos Aires; the work of Tonon, Mikkelsen, Rodriguez de la Vega and Toscano (2017) about neighborhood and housing as explanatory scales of children's quality of life and Tonon and Mikkelsen's work (2016) on housing inhabited by children in localities in the inner Buenos Aires province.

Children live in spaces, in precise geographical cuts, and this brings us closer to understanding studies on quality of life also in relation to the particular contexts of residence of the subjects studied. In this sense it is necessary to remember that the nearby territory, which became a place, in theoretical terms, implies a basic primary spatial unit. A specific position in the geographic space where a series of spatial interactions operate and define not only the physical environment, but also the identity of the subjects in it. The site participates in the construction of memories and projects a durability of time into the future (Clerc, 2004). In this sense, housing is a basic component of the quality of life of the subjects, defined by its configuration it is the place of refuge, family gatherings, enjoyment of life, a meeting place and a 
space for daily experiences (Lucero, Mikkelsen, Sabuda, Ares, Ondartz \& Aveni, 2008).

Housing is one of those places, it is the first place and the second territory. The body is the first territory, it is the closest that every person possesses and it is shaped from birth. The second territory comprises the family and those bodies that coexist within the framework of the house. This second territory refers to this domestic space where most primary activities are carried out, such as eating, sleeping and living with the family group. The house is the transition between body and community, while it is a unit on its own. The house is the basic unit of the neighborhood, town or city. From the housing groups a community is built, which would become a third level of the territory (Ramírez Velázquez \& López Levi, 2015).

Houses must protect their inhabitants from exposure, as well as provide thermal comfort and protection against substances or vectors that cause health risks. A house that does not meet the minimum requirements, in terms of materials, dimensions and sanitation, is associated with higher morbidity rates. In this way, the conditions of unhealthiness in the dwellings contribute negatively to the health of its inhabitants (Mikkelsen, Ares, Gordziejczuk, Picone \& Bruno, 2020). The possibility of access to housing should be understood as a human right recognized in international law as an integral element of the right to an adequate standard of living. In this regard, the work of Mitchell, Macció and Mariño Fages (2016) analyzed the effect of slum dwellings on the well-being of its inhabitants in Greater Buenos Aires.

Lack of access to housing in marginalized population groups is a central concern linked to lack of employment and stable income, which concurrently result in lack of basic services, promiscuity, overcrowding and various health impacts. Issues that also have a direct impact on the rest of the dimensions of the quality of life of subjects are Health, Education, Safety, Employment (Prieto, 2007).

It is important to remark that the materials used in the construction of the houses, the design of the houses and the spaces available therein, vary depending on the geographical space of their location, according to the culture and lifestyles of its inhabitants (Moreno Olmos, 2008).

There are many and different optics of analysis about the house, prevailing - usually - those readings that emphasize the physical or material aspect of it. However, and following García García (2014), it would be worth reflecting here on the notion of housing by rescuing its most subjective characteristics, understanding it as that environment in which family practices are accomplished, in which subjects learn and rehearse the family roles, values and customs of their community, and where the spheres of public and private life are defined. In other words, housing can be understood as a platform of intermediation between the individual (with his family circle) and the enlarged society.

Thus, the appeal to "lived-conceived space" (Lindón, Hiernaux and Aguilar, 2006 , p. 12) appears as a more fruitful notion to refer to housing, managing to focus mainly on the point of view of subjects and their articulation with the various uses and representations achieved around housing as a specific and unique place.

Within the house, the home takes place, because it arranges the activities of family and personal life. It also provides different basic services such as privacy, identity, environmental satisfaction or security (Ares, 2008). This close aspect of 
housing is what links it to the notion of home, underlining its potential to locate subjects in the world (Lindon (2005) in Ares, 2008).

Housing, then, assumes a clear role in this process, because in and through it, the contents of commonly appropriated daily knowledge is shared, departing from the most mundane problems of linking relationships. That is, in the space of housing the everyday becomes observable and there it is possible that the experiences of life inherited from the predecessor generations materialize.

\section{Methodology}

It is a descriptive cross-sectional study, developed by quantitative method, applying a questionnaire containing questions about housing and sociodemographic data of the participants. The questionnaire include one single question in Likert Scale mode (from 0 to 10 points where 0 is "Not satisfied at all" and 10 "Completely satisfied"), addresses children's level of satisfaction with the houses in which they live with their families.

The questionnaire was applied to children who attend public and private schools located in the District of General Pueyrredón.

In line with the ethical standards established by the current regulations in Argentina for research with persons, and especially with children attending school establishments, prior authorization was required from Education supervisors, as well as informed written consent from parents or guardians of each participating child. We respect the Code of Ethics established in the National Personal Data Law 25,326 (2000). The information that children provided was treated confidentially, with the corresponding ethical safeguards. The names of the participants are not used respecting the statistical secrecy.

Similarly, secondary data from the National Institute of Statistics and Census (INDEC, 2010) were consulted and analyzed in reference to population data, by houses and households of the witness sites considered for this research.

The sample consisted of 580 12-year-olds children-, living in different geographical areas (urban and rural) of General Pueyrredón district. This means a level of representation of the above-mentioned age group of $6.4 \%$. The different questions used in relation with housing are shown in Table 1.

SPSS 22.0 was used for data analysis: frequencies, percentages, means and crossover of variables were calculated. The Geographic Information System (GIS) was applied to construct thematic mapping, using the information that arises from the questionnaires and the official systematized information of the country.

The Geographic Information System (GIS) selected for map construction, is an open code system and it is called QGis, version 2.14.3. GIS is a tool that allows measurements and calculations of geo-referenced variables applied to analyze the selected dimensions, prioritizing individual characterization and then comparison, obtaining a set of synthetic thematic maps as final outcome. This, allowed us to generate geolocation maps referring to the areas involved in the study, giving spatial visibility and geographic context. 
Table 1 List of questions

How many rooms does your house have?

How many bathrooms does your house have?

Does your house have electricity?

Does your house have running water?

Does your house have a toilet?

Do you sleep in your own room or share the room?

Do you have your own bed?

Is there a place in your house where you can study quietly?

How satisfied are you with the house where you live?

Source made by the authors

\section{Results}

The study was carried out in localities of General Pueyrredón District (Map 1) which is located to the southeast of the province of Buenos Aires and amounts, according

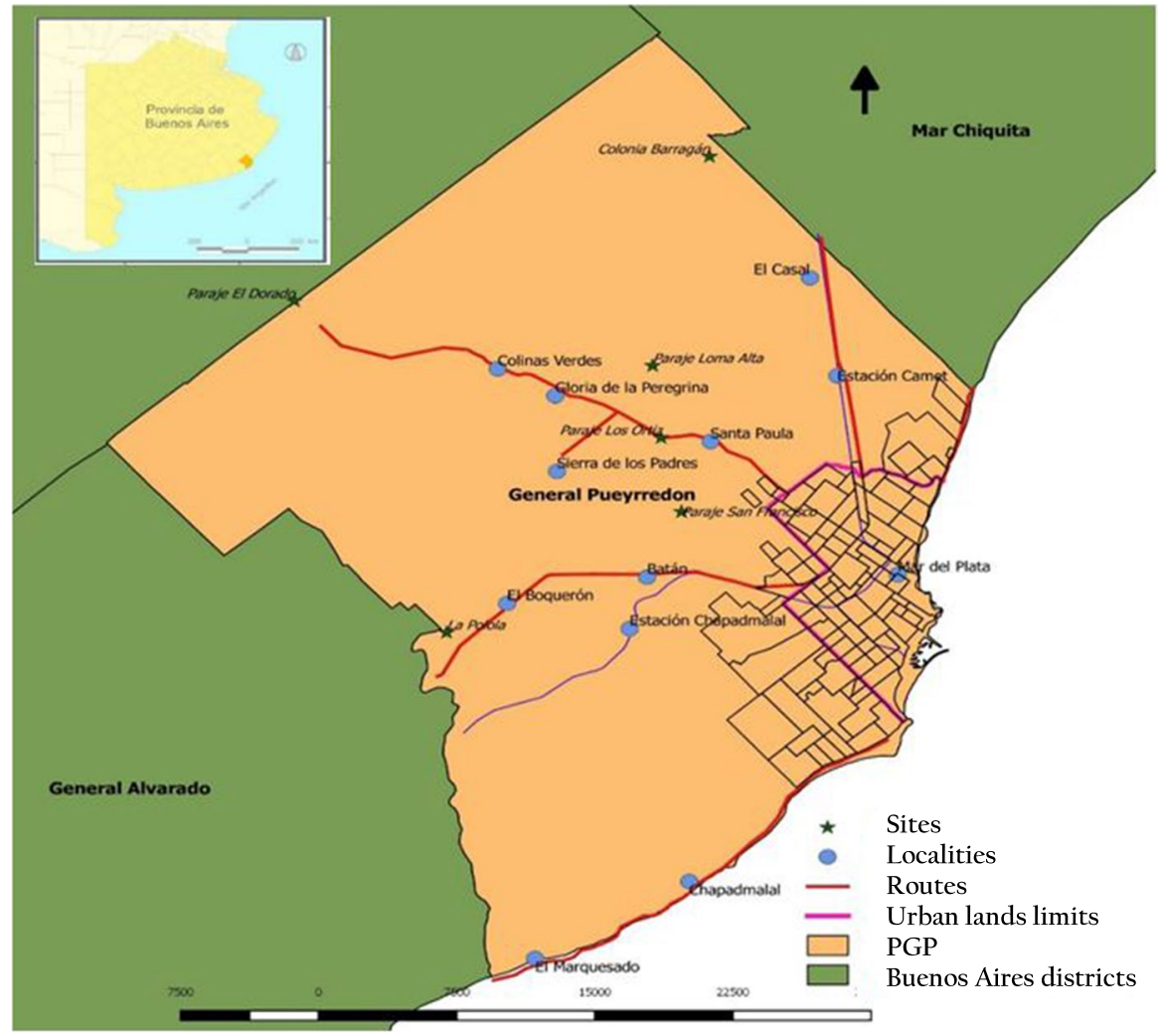

Map 1 General Pueyrredon District, Localities. (Source: made by the authors) 
to INDEC data for 2010 , to 618,989 inhabitants: $21.5 \%$ comprise the 0 to 14 year group, $64.2 \%$ bring together the potentially active population, i.e. 15 to 64 years of age, and $14.2 \%$ are ultimate passive population, i.e. they have more 65 years old. The PGP brings together 9066 children aged 12 years, 4641 are male and 4425 are female.

General Pueyrredón is a district characterized by its high urban concentration (98\%), organized in the agglomerate Mar del Plata-Batán-Camet, to which small towns (less than 5000 inhabitants) are added, and with significant population-housing growth in recent decades (Sagua, 2004, 2008; Ares \& Mikkelsen 2009; Ares, Mikkelsen, \& Sabuda 2011). These locations are consolidated as areas of residence not without problems, especially due to lacks in public services and distancing from Mar del Plata, a city with the greatest supply of activities and services. It should be noted that the qualifier of small or smaller cities is associated with the number of inhabitants that each town has and, therefore, with the range/size ratio to the agglomerate Mar del Plata-Batán-Camet.

General Pueyrredón district provides a wide range of activities and services related to tourism, extraction and transformation in relation to the primary resources associated with agriculture, livestock, fisheries, and horticulture. In its nearby territory, it exerts leadership roles over a set of population centers of lower rank and their respective areas of influence, with regard to educational, health, administrative and other services (Mikkelsen et al., 2013).

Specifically about the size of the PGP to be considered, in 2010 it contained 306,509 private homes, according to INDEC, of which $50.47 \%$ had satisfactory construction quality; $51.14 \%$ were built with construction quality 1 , this meant that the house had resistant and solid materials both on the floor and on the ceiling, and had a ceiling; and $53.02 \%$ of the houses had sufficient quality in connecting to basic services. In terms of systems of tenure, $65.52 \%$ of the households owned the house and the land, $20.40 \%$ were tenants; $7.26 \%$ were occupants per loan; $2.89 \%$ owned only the house, not the land; $1.65 \%$ were job occupants; and $1.99 \%$ referred to other situations.

In the context of the general characterization of the PGP indicated above, in order to reply to the intention set out in this article, public and private educational institutions in the local territory were used as a space for meeting the subjects under investigation. From all the educational institutions present in the PGP, given the age group selected for this research, secondary institutions, which are those that provide education from 12 years of age onwards as established by law in the national context, were due to be consulted. The survey was applied in ten (10) selected public and private educational institutions of the larger group pursuing the geographical representativeness of different sectors of the party (Map 2).

\subsection{Access to running water}

In General Pueyrredón, 92.56\% of households have water supply by public grid. Regarding the supply of running water, 462 children (80\%) stated that they have this 


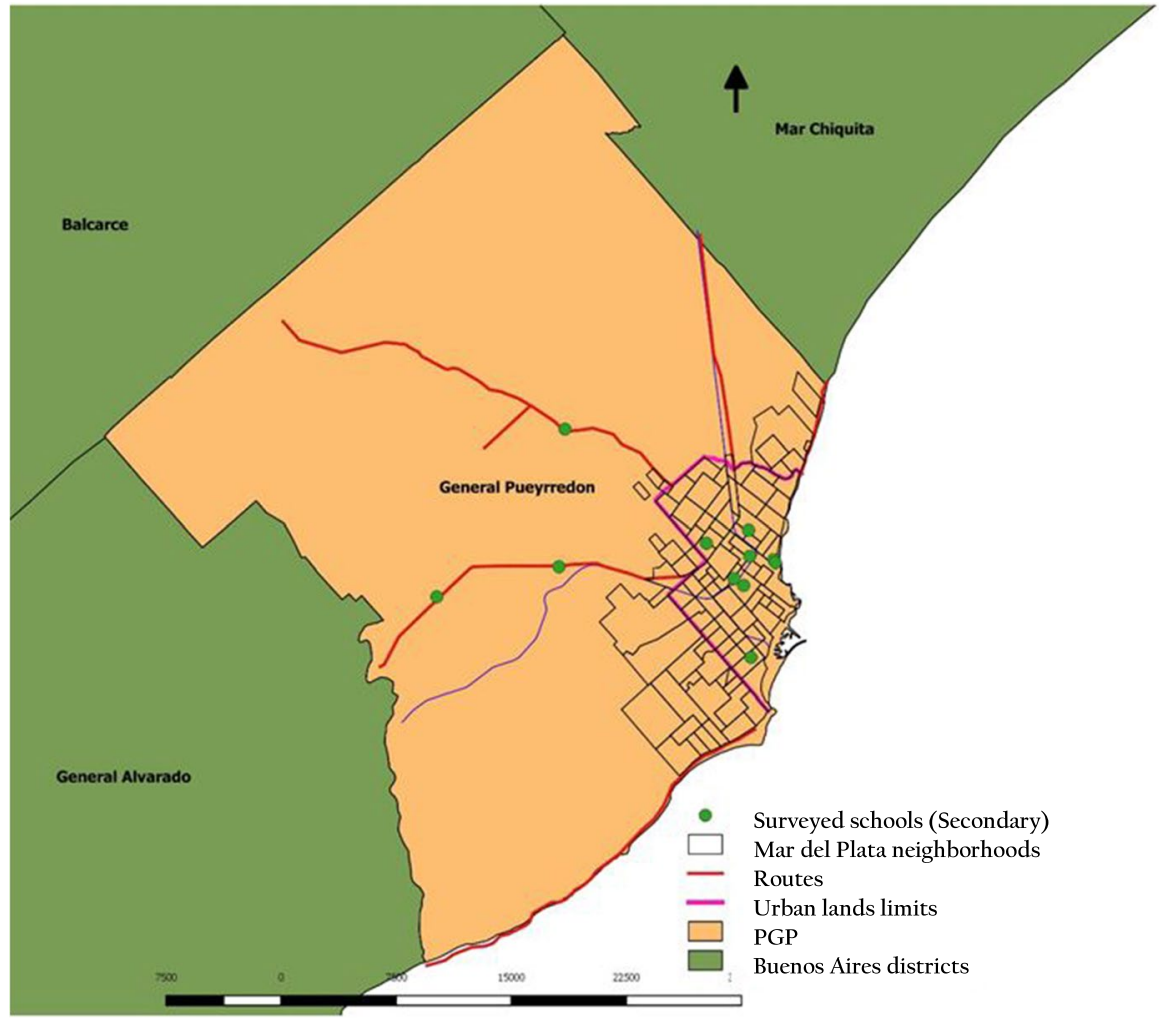

Map 2 Spatial location of surveyed high schools. PGP. 2018. (Source: made by the authors)

service in their homes, $43(7 \%)$ said no, $64(11 \%)$ expressed to be not sure and 11 (2\%) did not respond.

\subsection{Access to electricity}

According to the children sample considered, 559 children (96\%) show that they have electricity in their houses, 18 (3\%) show that this service sometimes allows for provisioning difficulties, and $3(1 \%)$ didn't report anything about it.

\subsection{Bathrooms in the house and possession of toilet in the house}

Within the framework of the district under study it is possible to establish that $97.7 \%$ of households have a bathroom for exclusive use. And of that set $95.06 \%$ has chain and water drag to the public grid. The overall average of bathrooms in the houses of the children studied is 2 (two), which is a high value. Regarding the provision of toilet pans 
in houses in the survey attained, 531 children (92\%) pointed out that their houses had toilet pans, only 3 indicated no, 6 were not sure and 40 did not know/answer.

\subsection{Rooms in the house, room for private use and possibility of own bed use}

On average, the number of rooms in the houses where the children studied reside is 4 (four). When consulted for privacy and the possibility of having their own rooms, the values obtained are quite stable since 246 children (42\%) point out that they sleep alone in a room so arranged for them, $329(57 \%)$ indicate that they share a room with another person, generally their siblings. While perceiving a low number of children (5) who preferred not to answer (Fig. 4).

Within the rooms, the possibility of having a bed for private use is in direct relation to overcrowding, in this sense, on the fact of having bed to sleep and rest, a high majority answered affirmatively 547 cases, i.e. 94\%, 27 children, i.e. 5\%, indicated that they should share their bed and 4 children (1\%) preferred not to answer.

\subsection{Place to study in the house}

With regard to having in the house a suitable space provided with what is necessary to study and develop schoolwork, we find that 412 children (71\%) have a place in their houses available for the execution of tasks demanded from educational institutions, 64 children $(11 \%)$ do not have the aforementioned space, 99 children (17\%) are not sure, and $5(1 \%)$ did not answer. This data contributes to the understanding of the functionality of the house as the perception they have about whether the housing spaces and the facilities of the house are appropriate for family life (Landáruzi \& Mercado, 2004).

\subsection{Satisfaction with house of residence}

This question addresses the level of satisfaction of the interviewed children regarding the houses in which they reside with their families. This is a question in Likert Scale mode from 0 to 10 points where 0 is "Not satisfied at all" and 10 "Completely satisfied".

While the mean at the satisfaction level is high: 8.885 , it has a standard deviation of 1.840, which shows a high level of responses dispersion, Table 2.

Graphic 1 shows a high number of responses with level of satisfaction of 10 points, we can precisely point out that $52 \%$ of the children in the sample point to this value in their replies.

Table 2 Means

\begin{tabular}{lll}
\hline $\mathrm{N}$ & Mean & Standard deviation \\
\hline 580 & 8.85 & 1.840 \\
\hline
\end{tabular}

Source made by the authors 


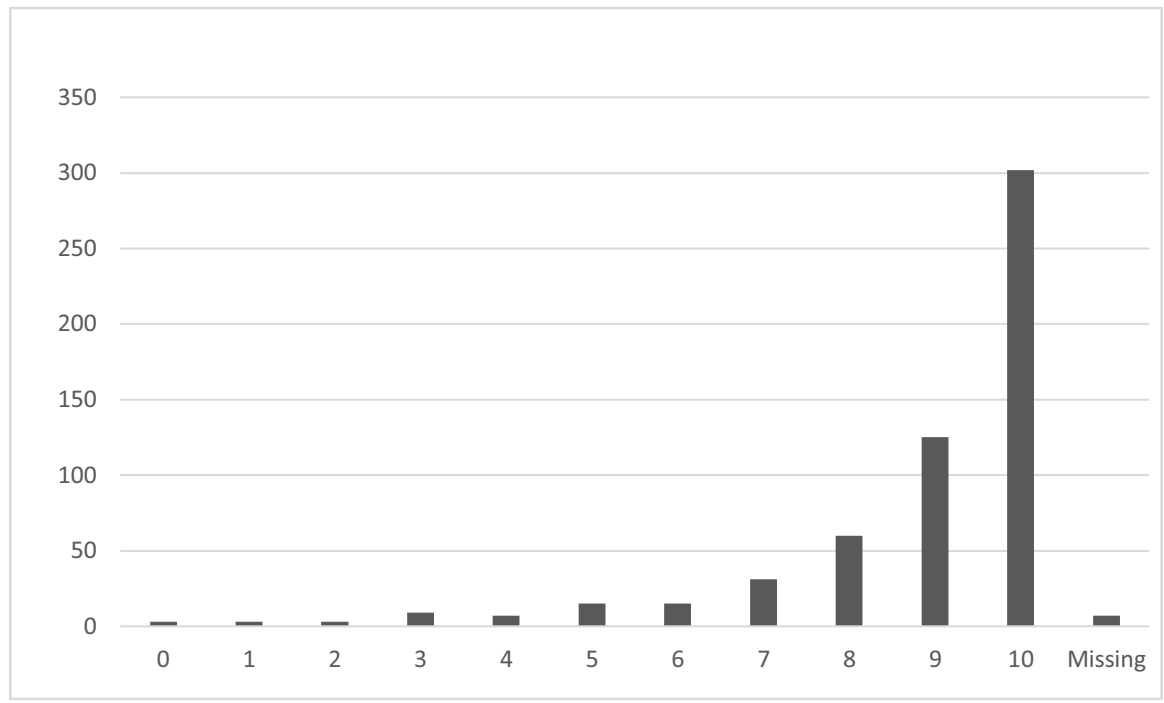

Graphic 1 Satisfaction with house of residence, children 12 years of age PGP. 2018. Source: made by the authors on primary data survey 2018

\section{Discussion}

Housing is a fundamental need for the development of a dignified life together with healthy eating and the possibility of suitable clothing, in addition to accessing education and health (Leventhal \& Newman, 2010).

As established by WHO (1990) the means used by society to meet this need are diverse in terms of the materials employed for construction, site of placement, climate comfort, income, among other issues. In this sense, the geographical spacesociety link is essential since both condition each other on the decisions applied in terms of housing construction. As for the forms of housing tenure also the possibilities are wide (purchase, rent, loan, session, among others). In addition, the eventuality of accessing a household is directly linked to the job of its inhabitants, that is, the economic activity that they develop and consequently their level of income. Previous studies point to the importance of housing ownership for children as it promotes adolescents' achievement if compared with renting (assisted or unassisted) because it provides greater stability and possible access to higher quality schools (Pribesh \& Downey, 1999; Coley et al., 2013).

Considering each of the indicators evaluated, the relevance of achieving the construction of other indicators stands out, referring to the different forms of access to water supply (public network, pump, well, rain among others) and the various uses of electricity (heating, power, use of electrical appliances) identifying the specificities that appear both in contexts of urbanity and rurality, since the accessibility conditions in each of these contexts are different. Likewise, inquiring into the characteristics of home habitability, the number of rooms, the functions that these rooms have for the domestic unit, the needs that are covered in those spaces of the house and the 
difficulties that arise, understanding that houses not only define a material environment of equipment but they are also the environment that provides support for the harmonious development of children.

Water consumption attains a substantial role in human survival, therefore it is essential for our sustenance and also for the performance of numerous activities. Having water supply per pipe within the house is not only beneficial but also necessary for the achievement of good health quality of the population, therefore it is positively valued in their well-being. Added to this situation, the form of supply of this water, i.e. the fact that it comes from a public network or from motor pump drilling, increases benefits to the health of the residents in the houses (Mikkelsen, Ares, Gordziejczuk, Picone \& Bruno, 2020). Having some infrastructure linked to the provision of water, the elimination of excreta and drains are important contributions in the prevention and fight against certain diseases, essentially in vulnerable groups such as children and the elderly. In the context of the PGP, data show favorable circumstances in the households in which children live with their families regarding the provision of safe water. As Caceres and Rodríguez-Bilella (2014) state, water is a key element in meeting the basic needs of society, a decisive factor for human progress and a fundamental aspect to ensure a dignified life. However, the United Nations (UN) report on the millennium development goals set for 2015 reveals that, despite improvements in access to safe drinking water, a large proportion of the world's population and especially children are still lacking water supplies through pipes. Difficulties in accessing safe water are directly related to the risk of intestinal and stomach diseases. Access to safe water is a primary right since in childhood its lack can obstruct the appropriate human, physical and cognitive development.

Closely related to the indicators previously considered, the possibility of accessing electric light in the context of modernity today also becomes a fundamental element in terms of the quality of life of residents in housing. The United Nations and the World Bank emphasize the importance of accessing the use of electricity as key indicators in order to reduce poverty and improve the living conditions of the world population (UN 2010). Our life turns around the use of technological devices that demand for its operation the use of electric energy. It is interesting to reflect on communication as a right. In this regard, Kenny, Navas-Sabater and Qiang warn that ICTs (Information and Communication Technologies) provide access to information that can create opportunities to generate income, improve access to basic services, or increase the impact of interventions on education and health. ICT also gives the poor a voice to demand support and changes from the government (Kenny et al., 2000). In this sense, connectivity in children is increasingly a right that all children should have, as well as the provision of electricity for the development of their educational and recreational work, and as the use of safe and non-polluting energies for food processing and heating, and to access the use of new ICTs.

Having a bathroom in the house is a requisite of living conditions in general and for the health of its residents in particular. The presence of a room defined as a bath tells about the possibility of having connection to safe water and to the sewage networks that allow the withdrawal of the sewage. In this sense, it refers not only to the possibility of access to housing but to the role that the State must play in bringing to its citizens basic services such as water and sewers, specifically in urban areas. As 
Velázquez et al. (2020) expresses, the lack of such a basic element as the toilet pan highlights the lack of housing equipment. This element depends on the individual situation of the family and the house and, unlike others such as water supply or sewerage, is independent of its location within respect to a network established for such a purpose.

The availability of rooms in the house is in direct association to the overcrowding of the members of the household depending on the rooms available in the house. As stated by Velazquez et al. (2020), the link between the number of residents in the house and the number of rooms shows a significant aspect: the housing deficiency in relation to the number of its inhabitants. Overcrowding in households implies a number of difficulties, as it contributes to disease transmission and is related, in turn, to violence (World Health Organization, 1990). In the PGP, INDEC reports by $2010,14.18 \%$ of households are overcrowded (2 or more people per room). These are comparatively low values of critical overcrowding.

In greater detail, the inquiry allowed information to be recovered on the possibility of having a bed for private use in the rooms arranged as bedrooms. The fact that there is a bed for private use is also directly associated with experiencing overcrowding or not, and with problems of diseases, promiscuity and lack of privacy.

In addition to the possibility of possessing a house, and that it includes essential services for the development of a dignified life, it is important to refer to the design and size of the houses. So it is not only about owning a house but also ensuring minimum comfort and habitability. Habitability is the attribute of the spaces built to meet the objective and subjective needs of the individuals and groups that inhabit them (Landáruzi \& Mercado, 2004), refers to the necessary link between the house and its inhabitants, between the design given to the house and the use that its members make of it.

In this sense, data on overcrowding and certain equipment was recovered, with this indicator the emphasis is placed on reflecting on the importance for children to have within the house an appropriate space in which to study and perform schoolwork. This data contributes to the understanding of the functionality of the house understood as the perception felt about whether the housing spaces and the facilities of the house are appropriate for family life (Landáruzi \& Mercado, 2004).

Housing satisfaction aims to capture the influence of one's dwelling characteristics on subjective well-being. In the 90s Davis and Fine Davis (1991) found that housing satisfaction is positively associated with life satisfaction. The authors identified the factors associated with housing satisfaction which are: the construction quality, plan, and design of the house; the dwelling size; the adequacy of interior space; the housing amenities; and the price of the dwelling. After three decades, the results of Morautidis study (2020) showed that housing satisfaction is significantly associated with subjective well-being and it is an indicator of livability and quality of life within cities.

In our study it is stimulating to find that the level of satisfaction with housing is high, although it also presents a high level of dispersion. In an earlier study with children aged 8 and 10 in the Province of Buenos Aires (Tonon \& Mikkelsen, 2016), in which a Likert scale of 0 to 4 points was worked on, corresponding 4 to "totally satisfied" and 0 to "totally dissatisfied", $80.5 \%$ of 8-year-olds (N 590) answered to 


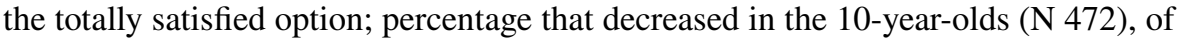
whom $71.7 \%$ chose this option of answer.

\section{Conclusions}

Considering that in Latin America the first studies on the lives of children in relation to their houses were developed as of the twenty-first century, it was a challenge for us to address the opinions of children in relation to the houses they inhabit; likewise, the important contribution that a discipline such as Geography can make was revealed.

The most significant results of our study showed that $97.7 \%$ of the houses inhabited by the children have a bathroom for exclusive use, $92.56 \%$ have water supply through the public network and $96 \%$ have electricity, $42 \%$ of the children state that they sleep in their own room, $94 \%$ have their own bed and $71 \%$ have a place in the house for the development of schoolwork. These values make it clear that the habitability conditions of the houses occupied by boys and girls do not show characteristics of overcrowding. Likewise, it is important to mention that, although the average level of satisfaction with the home is high: 8.885, the standard deviation is 1.840, which showed a high level of dispersion in the responses.

The set of results obtained in this study showed the intellectual need to continue advancing and deepening on the study of the housing dimension in the larger field of studies on child well-being. Therefore, it is imperative to approach the study of housing in a comprehensive manner, simultaneously evaluating the different aspects that promote or inhibit specific family arrangements.

The right to decent housing for society as a whole, but for children in particular, guarantees the possibility of growing up healthy, cared for, having better school performance, potentially ensuring their future job placement and their development as a responsible and empathetic citizen. Housing is the first place of socialization, it is the second territory, which provides the skills to approach life in community and in society.

Conflict of interests None.

\section{References}

Ares, S. (2008). Del "sueño de la casa propia" a las desventajas del alejamiento. Tenencia de la vivienda y calidad de vida en localidades menores del Partido de General Pueyrredón. In P. Lucero (Dir.), Territorio y Calidad de Vida: una mirada desde la geografía local, 335-365. EUDEM.

Ares, S. \& Mikkelsen, C. (2010). Nuevas dinámicas residenciales en los asentamientos rurales del litoral sudeste pampeano. Breves Contribuciones del Instituto de Estudios Geográficos, N²1, 104-134. Universidad Nacional de Tucumán.

Ares, S., Mikkelsen, C. \& Sabuda, F. (2011). Identificación de localidades en el Partido de General Pueyrredón a partir de la implementación de Tecnologías de Información Geográfica (TIGs). GEOGRAFICANDO, número 7, 51-68. Departamento de Geografía. Facultad de Humanidades y Ciencias de la Educación. Universidad Nacional de La Plata. 
Ben-Arieh, A. (2010). From child welfare to children wellbeing: The child indicators perspective. Children's Well-Being: Indicators and Research, 1, 9-22. https://doi.org/10.1007/978-90-481-3377-2

Bradshaw, J., \& Richardson, D. (2009). An index of child well-being in Europe. Child Indicators Research, 2(3), 319-351. https://doi.org/10.1007/s12187-009-9037-7

Cáceres, D M. \& Rodríguez-Bilella, P. (2014). Acceso y apropiación del agua en comunidades rurales pobres de Argentina central. Transformaciones y conflictos. Revista Economía, Sociedad y Territorio, vol. XIV, núm. 45, 359-395.

Caramelo, G. (2018) Niñez y derecho a la vivienda. Revista del ministerio Público de la Defensa de la Nación. 199-211. http://www.pensamientopenal.com.ar/system/files/2018/12/doctrina47200.pdf.

Clerc, P. (2004). Lugar. Hypergéo, encyclopédie électronique. http://www.hypergeo.eu/spip.php?artic le331\#.

Coley, R. L., Leventhal, T., Lynch, A. D., \& Kull, M. (2013). Relations between housing characteristics and the well-being of low-income children and adolescents. Developmental Psychology, 49(9), 1775-1789. https://doi.org/10.1037/a0031033

Davis, E. E., \& Fine-Davis, M. (1991). Social indicators of living conditions in Ireland with European comparisons. Social Indicators Research, 25, 103-365. https://doi.org/10.1007/BF00286160

Evans, G. W., Saltzman, H., \& Cooperman, J. L. (2001). Housing quality and children's socioemotional health. Environment and Behaviour, 33(3), 389-399. https://doi.org/10.1177/00139160121973043

García García, D. M. (2014). Calidad, satisfacción y demografía residencial. Una visión conceptual de enfoques y tensiones de las teorías. Cuadernos de vivienda y urbanismo, 7(14), 260-275.

Gorelik, A. (2015). Ensayo introductorio. Terra incógnita. Para una comprensión del Gran Buenos Aires como Gran Buenos Aires. En G. Kessler (Dir.), Historia de la provincia de Buenos Aires: el Gran Buenos Aires, (pp. 21-69). UNIPE-Editorial Universitaria.

Hanafin, S. \& Brooks, A. M. (2005). Report on the development of a national set of child well-being indicators in Ireland. The National Children's Office. http://217.35.77.12/archive/republic/papers/welfa re/pdfs/Report_on_the_Development_of_a_set_of_Child_Well_Being_Indicators.pdf. Accessed 9 Dec 2021

Harkness, J., \& Newman, S. J. (2005). Housing affordability and children's well-being: Evidence from the national survey of America's families. Housing Policy Debate, 16(2), 223-255. https://doi.org/ $10.1080 / 10511482.2005 .9521542$

INDEC. (2010) Censo Nacional de Población, Hogares y Viviendas 2010.https://www.indec.gob.ar/ indec/web/Nivel4-CensoProvincia-999-999-06-000-2010. Accessed 9 Dec 2021

Kenny, CH., Navas-Sabater, J. \& Qiang, CH. (2000) Tecnologías de la información y comunicaciones (ICT) y la pobreza. http://siteresources.worldbank.org/INTPRS1/Resources/383606-1205334112 622/4768783-1205337105916/ict0212.pdf. Accessed 9 Dec 2021

Landáruzi, M. \& J. Mercado (2004). Algunos factores físicos y psicológicos relacionados con la habitabilidad interna de la vivienda. Medio Ambiente y Comportamiento Humano. Vol. Núms. 1 y 2. 89-113. Tenerife: Facultad de Psicología. Universidad de la Laguna.

Leventhal, T., \& Newman, S. (2010). Housing and child development. Children and Youth Service Review, 32(9), 1165-1174. https://doi.org/10.1016/j.childyouth.2010.03.008

Lindón, A., Hiernaux, D. \& Aguilar, M. A. (2006). De la espacialidad, el lugar y los imaginarios urbanos: a modo de introducción. In A. Lindón, M. A. Aguilar \& D. Hiernaux (Coords.), Lugares e imaginarios en la metrópolis, 9-25. Anthropos y Universidad Autónoma Metropolitana.

Lopes de Souza, M. (1995) O territorio: sobre espaço e poder, autonomía e desenvolvimento. In I De Castro,; P. da Costa Gomes, \& R. Lobato Correa, Geografía: conceitos e temas. 77-116. Bertrand Edit.

Lucero, P., Mikkelsen, C. Sabuda, F., Ares, S., Ondartz, A \& Aveni, S. (2008). Calidad de vida y espacio: una mirada geográfica desde el territorio local. En P. Lucero, (Dir.). Territorio y Calidad de Vida: una mirada desde la geografía local. Mar del Plata y Partido de General Pueyrredón, 79-109. EUDEM.

Mieles Barrera, M. D. \& Tonon, G. (2015). Calidad de vida y niñez: perspectivas desde la investigación cualitativa. UNIMAGDALENA, Universidad de Magdalena.

Mikkelsen, C. \& Tonon, G. (2016) Aproximación al estudio de la calidad de vida de niños y niñas en localidades del interior de la provincia de Buenos Aires (Mar del Plata, Tandil, Balcarce y San Cayetano) y del Conurbano Bonaerense (Lomas de Zamora, Banfield y Ramos Mejía), 2014-2015. In D. Lan, (comp.) Geografías en Diálogo. Aportes para la reflexión Tomo 1. Universidad Nacional del Centro de la Provincia de Buenos Aires. 84-91. https://es.scribd.com/document/334628472/Geogr afias-en-dialogo-Aportes-para-la-reflexion-Tomo-I. 
Mikkelsen, C.; Ares, S.; Gordziejczuk, M., Picone, N. \& Bruno, M. (2020). El bienestar de la población rural argentina (2010). In: G. Velazquez, y J. P. Celemin, (dir.) Configuración y reconfiguración socioterritorial de la Argentina en tiempos del bicentenario, Tomo 1. 637-659. Universidad Nacional del Centro de la Provincia de Buenos Aires.

Mitchell, A., Macció, J. \& Mariño Fages, D. (2016) El efecto de la vivienda de emergencia en el bienestar. ANALES- Asociación Argentina de Economía Política. Noviembre. 1-22. https://repositorio. uca.edu.ar/bitstream/123456789/9404/1/efecto-vivienda-emergencia-bienestar.pdf.

Morautidis, K. (2020). Commute satisfaction, neighborhood satisfaction, and housing satisfaction as predictors of subjective well-being and indicators of urban livability. Travel Behaviour and Society, 21, 265-278. https://doi.org/10.1016/j.tbs.2020.07.006

Moreno Olmos, S., (2008) La habitabilidad urbana como condición de calidad de vida. Palapa, vol. III, núm. II, julio-diciembre, 47-54. Universidad de Colima. México.

Nuñez, M. (2012). Una aproximación desde la sociología fenomenológica de Alfred Schütz a las transformaciones de la experiencia de la alteridad en las sociedades contemporáneas. Sociológica (Méx.), 27(75) ene./abr, 49-67. http://www.scielo.org.mx/pdf/soc/v27n75/v27n75a2.pdf

ORGANIZACIÓN DE LAS NACIONES UNIDAS (ONU) (2010). Resolución A/RES/65/151: Año Internacional de la Energía Sostenible para Todos. New York, p. 1-3.

ORGANIZACIÓN DE LAS NACIONES UNIDAS (ONU) (n.d.). Objetivos de desarrollo del milenio. www.undp.org/content/undp/es/home/sdgoverview/mdg_goals.html.

Organización Mundial de la Salud (OWS) (1990). Principios de Higiene de la vivienda. Ginebra.

Pavot, W., \& Diener, E. (1993). Review of satisfaction with life scale. Psychological Assesment, 5(2), 164-172. https://doi.org/10.1037/1040-3590.5.2.164

Pribesh, S., \& Downey, D. B. (1999). Why are residential and school moves associated with poor school performance? Demography, 36, 521-534. https://doi.org/10.2307/2648088

Prieto, M.B. (2007). Condiciones habitacionales y calidad de vida urbana. El caso de la ciudad de Bahía Blanca. IX Jornadas Argentinas de Estudios de Población. Asociación de Estudios de Población de la Argentina, Huerta Grande. https://www.aacademica.org/000-028/121. Accessed 9 Dec 2021

Ramírez Velázquez, B. \& López Levi, L. (2015) Espacio, paisaje, región, territorio y lugar: la diversidad en el pensamiento. UNAM, Instituto de Geografía. https://web.ua.es/es/giecryal/documentos/ blanca-uam.pdf. Accessed 9 Dec 2021

Rees, G., \& Bradshaw, J. (2017). Exploring low subjective well-being among children aged 11 in the UK: An analysis using data reported by parents and by children. Child Indicators Research, 11, 27-56. https://doi.org/10.1007/s12187-016-9421-z

Rees, G., Tonon, G., Mikkelsen \& Rodriguez de la Vega, L. (2017) Urban-rural variations in children's lives and subjective well-being: A comparative analysis of four countries. Children and Youths Service Review, Vol 80 September 2017, Special Issues Children's Worlds. pp. 41-51. DOI: https://doi. org/10.1016/j.childyouth.2017.06.056 http://www.sciencedirect.com/science/article/pii/S019074091 7305418 .

Sagua, M. (2004) Dinámica sociodemográfica y ambiente al interior del Partido de General Pueyrredon. In G. Velázquez, , P. Lucero, \& J. M. Mantobani, (Autores y Editores) (2004). Nuestra Geografía Local. Población, urbanización y transformaciones socio-territoriales en el Partido de General Pueyrredon, Argentina, 1975-2000. GESPyT, FH, UNMdP. pp. 129-165.

Sagua, M. (2008). Habitar las localidades menores del Partido de General Pueyrredon. In: P. Lucero, (Dir) Territorio y calidad de vida, una mirada desde la geografía local. EUDEM. Pp 355-385.

Santos, M. y Silveira, M. L. (2001). O Brasil. Territorio e sociedade no inicio do século XXI. Editora Record.

Tonon, G. (2018a). Opinions, life experiences, and definitions of children, young people, and university students from the Province of Buenos Aires. In S. Kenny, B. McGrath and R. Phillips (Editors) The Routledge handbook of community development. Routledge, Taylor and Francis. Chap. 18.

Tonon, G. (Comp.), (2018b) Conocer la calidad de vida de niños y niñas desde las palabras de sus protagonistas. Facultad de Ciencias Sociales.

Tonon, G. \& Mikkelsen, C., (2016) La casa y las personas con las que viven niños y niñas. In G. Tonon, , C. Mikkelsen, , L. Rodriguez de la Vega, \& W. Toscano, Investigar la calidad de vida de niños y niñas. Colección Científica UNICOM, 26-37. Año 4, Número 8.

Tonon, G. \& Mikkelsen, C. (2017). El barrio como espacio social desde la mirada de niños y niñas que viven en ciudades de la Provincia de Buenos Aires. In Tavano, C. (coordinadora) Libro de las I Jornadas de Sociología de la Universidad Nacional de Mar del Plata. 1902-1919. Universidad Nacional de Mar del Plata. 
Tonon, G. \& Mikkelsen, C. (2019) El lugar desde la mirada de los/as niños/as, un aporte a la geografía de la niñez, In Libro del VII Congreso Nacional de Geografía de Universidades Publicas y XXI Jornadas de Geografía de la UNLP. (pp. 1-24) Facultad de Humanidades y Ciencias de la Educación. http://jornadasgeografia.fahce.unlp.edu.ar. Accessed 9 Dec 2021

Tonon, G. \& Mikkelsen, C. (2021) Children's satisfaction with the neighborhood in the province of Buenos Aires, Argentina. International Journal of Happiness and Development. First online January 2021. https://www.inderscience.com/info/ingeneral/forthcoming.php?jcode=ijhd. Accessed 9 Dec 2021

Tonon, G., Mikkelsen, C., de la Rodríguez Vega, L. \& Toscano, W. (2017). Neighborhood and housing as explanatory scales of children's quality of life. In J. Sarriera y L. Bedin (Eds.), Psychosocial wellbeing of children and adolescents in Latin America, 91-107. Springer.

Velázquez, G.; Celemín, J. P.; Gómez Lende, S.; Manzano, F., Mikkelsen, C \& Arias, M. E. (2020) Calidad de vida en 2010. In: G. Velazquez, \& J. P. Celemin, (dir.) Configuración y reconfiguración socioterritorial de la Argentina en tiempos del bicentenario. Universidad Nacional del Centro de la Provincia de Buenos Aires. Tomo 1, 195-264. https://www.fch.unicen.edu.ar/atlashyg/atlascv1eb ook.pdf.

Publisher's Note Springer Nature remains neutral with regard to jurisdictional claims in published maps and institutional affiliations. 